\title{
THE APPLICATION OF LIQUID ORGANIC FERTILIZER FROM BANANA PSEUDOSTEM ON GROWTH AND YIELD OF SWEET CORN (ZEA MAYS SACCHARATA)
}

\author{
Syawal Yernelis, Sodikin Erizal, Irmawati \\ Department of Agronomy, Faculty of Agriculture, University of Sriwijaya, Indonesia \\ ${ }^{*}$ E-mail: irmawati@fp.unsri.ac.id
}

\begin{abstract}
Due to its abundance availability, banana pseudostem has been considered as potential resource for organic fertilizer in order to decrease dependencay on synthetic fertilizers. Thus, this research was aimed to evaluate the application of liquid organic fertilizer originated from banana pseudostem on growth and yield of sweet corn. The experiment was carried out in Experimental Farm of Department of Agronomy, University of Sriwijaya from January to April 2016. It was resulted that all parameters observed showed better response to $P_{3}$ compared to other treatments. Furthermore, the application of banana pseudostem liquid organic fertilizer was believed could increase soil mineral nutrients content.
\end{abstract}

\section{KEY WORDS}

Banana pseudostem, liquid organic fertilizer, sweet corn, yield.

The demand of sweet corn has been increasing as it is a popular food commodity due to the sweet taste and high nutrient content (Martajaya et al., 2010). It is mainly utilized as main ingredient for either processed foods or non food processed products, as well as the substitute for rice as the staple food. Considering the environmental effect, sweet corn cultivation using organic fertilizer has been performed in various areas. It is considered much safer and has less chemical residues compared to synthetic fertilizer. Nasution (2014) has studied the application of solid and liquid organic fertilizer from banana peel on lettuce (Brassica juncea L.) with the dosages of 15, 25, 35, 45 and $55 \mathrm{ml}$ of liquid fertilizer. It was resulted that optimal dose for growth of lettuce plant was $25 \mathrm{ml}$ per plant. Soluble nutrients in liquid fertilizer benefits plant growth through improved nutrient use efficiency and minimize nutrient loss resulted in higher yield production (Toonsiri et al., 2016).

Banana pseudostem is considered as a potential resource for organic fertilizer due to its abundance availability since most banana growers generally will just let the pseudostem (and the underground stem) rot on the ground after harvesting. Some research has been reported chemical content on the extract of banana pseudostem, such as tannins, saponins and flavonoids. Saponins are glycosides substances contained in various plant species which have excellent properties for plant tissue development (Sugiarti, 2011). Bahtiar et al. (2016) reported high concentration of macronutrients contained in banana stem consisting of $3087 \mathrm{ppm} \mathrm{NO}, 1120 \mathrm{ppm} \mathrm{NH} \mathrm{N}_{4}, 439 \mathrm{ppm} \mathrm{P}_{2} \mathrm{O}_{5}$ and $574 \mathrm{ppm} \mathrm{K} \mathrm{K}_{2} \mathrm{O}$. Similar results was reported by Suprihatin (2011) studying the existence of $\mathrm{Ca}, \mathrm{P}$ and $\mathrm{K}$ in banana stem. From the extraction, it was found that the concentration of $\mathrm{Ca}, \mathrm{P}$, and $\mathrm{K}$ were $16.2 \%$ weight, $30.05 \%$ weight and $21.5 \%$ weight respectively with solvent volume of $600 \mathrm{ml}$ and 15 minutes of stirring time.

However, the potency of banana pseudostem as organic fertilizer has not been widely studied. Thus, this study was aimed to evaluate the growth and yield of sweet corn by the application of liquid organic fertilizer from banana pseudostem.

\section{METHODS OF RESEARCH}

This research was conducted in Experimental Farm of Department of Agronomy, Faculty of Agriculture, University of Sriwijaya, Indralaya started from January until April 2016. Randomized Block Design was used with 7 dosage treatments and 4 replicates resulting in total 28 treatment units. Sweet corn was planted on separate plot based on each treatment 
with the size of $3.3 \mathrm{~m} \times 3.5 \mathrm{~m}$ per plot and $70 \mathrm{~cm} \times 30 \mathrm{~cm}$ planting space. The treatments were the dosage of liquid fertilizer consisted of: $P_{0}=$ control, $P_{1}=400 \mathrm{ml}$ per plot, $\mathrm{P}_{2}=800$ $\mathrm{ml}$ per plot, $\mathrm{P}_{3}=1,200 \mathrm{ml}$ per plot, $\mathrm{P}_{4}=1,600 \mathrm{ml}$ per plot, $\mathrm{P}_{5}=2,000 \mathrm{ml}$ per plot, and $\mathrm{P}_{6}=$ $2,400 \mathrm{ml}$ per plot.

The observed parameters included plant height $(\mathrm{cm})$, number of leaves per plant, tasseling time (day), cob weight with husk per plant $(\mathrm{g})$, cob weight without husk per plant $(\mathrm{g})$, cob length $(\mathrm{cm})$, cob diameter $(\mathrm{cm})$, cob weight with husk per plot $(\mathrm{kg})$, and cob weight without husk per plot $(\mathrm{kg})$.

\section{RESULTS AND DISCUSSION}

Plant cultivation has been heavily depended on fertilizer as its nutrient source during its growth and development stages. The use of organic fertilizer has been a trending issue in order to confront the dependancy of synthetic fertilizer concerning the environmental value. Banana pseudostem was used as the main ingredient of liquid fertilizer applied on sweet corn in this research. The effect of liquid organic fertilizer then was confirmed by evaluating both growth and yield parameters of sweet corn. Based on the analysis of variance, the application of liquid organic fertilizer from banana pseudostem significantly affected all observed parameters, except for tasseling time as given in Table 1.

Growth parameters. Growth parameters observed in this study included plant height (cm), leaf number, and tasseling time (day). However, based on the analysis of variance, only plant height and number of leaves were significantly affected by the application of liquid organic fertilizer.

Table 1 - Analysis of variance of liquid fertilizer application on growth and yield parameters of sweet corn

\begin{tabular}{lllll}
\hline No & Parameters & F value & F 0.05 & Coeficient of variance \\
\hline 1 & Plant height (cm) & $15.96^{*}$ & 2.53 & $9.95 \%$ \\
2 & Leaf number & $15.00^{*}$ & 2.53 & $2.77 \%$ \\
3 & Tasseling time (day) & $1.91^{\text {ns }}$ & 2.53 & $1.79 \%$ \\
4 & Cob weight with husk (g) & $70.56^{*}$ & 2.53 & $4.28 \%$ \\
5 & Cob weight with husk per plot $(\mathrm{kg})$ & $0.05^{*}$ & 2.77 & $3.39 \%$ \\
6 & Cob weight without husk (g) & $47.13^{*}$ & 2.53 & $5.21 \%$ \\
7 & Cob weight without husk per plot $(\mathrm{kg})$ & $2.56^{*}$ & 2.77 & $2.40 \%$ \\
8 & Cob length $(\mathrm{cm})$ & $35.06^{*}$ & 2.53 & $4.92 \%$ \\
9 & Cob diameter $(\mathrm{cm})$ & $27.37^{*}$ & 2.53 & $2.37 \%$ \\
\hline
\end{tabular}

Note: * significant in F0.05; $n s=$ non significant

The application of $1,200 \mathrm{ml}$ of liquid fertilizer dosage (P3) showed the best result by having the highest plant with $159.60 \mathrm{~cm}$, while the shortest was from P6 treatment with 85.40 $\mathrm{cm}$ (Table 2).

Table 2 - The effect of liquid organic fertilizer application on plant height and leaf number of sweet corn on the $7^{\text {th }}$ week

\begin{tabular}{lll}
\hline Treatment & Plant height $(\mathrm{cm})$ & Leaf number \\
\hline Control & $110.02 \mathrm{~b}$ & $11.00 \mathrm{a}$ \\
P1 & $117.72 \mathrm{bc}$ & $12.00 \mathrm{~b}$ \\
P2 & $136.50 \mathrm{~d}$ & $12.00 \mathrm{~b}$ \\
P3 & $159.60 \mathrm{e}$ & $13.00 \mathrm{c}$ \\
P4 & $131.48 \mathrm{~cd}$ & $12.00 \mathrm{~b}$ \\
P5 & $105.82 \mathrm{~b}$ & $11.00 \mathrm{a}$ \\
P6 & $85.40 \mathrm{a}$ & $11.00 \mathrm{a}$ \\
\hline LSD 5\% & 17.89 & 0.50 \\
\hline
\end{tabular}

Means followed by the same letters in the same column are not significantly different at the $5 \%$ LSD level.

The effect of liquid organic fertilizer application on the increase of plant height is given in Figure 1. It was found that there was an increasing trend of plant height following the 
increase of liquid fertilizer dosages. However, the height was gradually decreased after reaching the optimum level at P3 treatment and started decreasing afterwards. The highest dosage $(2,400 \mathrm{ml}$ per plot) even resulted the shortest height, even lower compared to control. Such trend was more apparent after $5^{\text {th }}$ week observation.

Similar result was found in leaf number parameter showing P3 as the treatment with best result. Treatment P3 showed the best result by having most leaf number with 13 leaves, and was significantly different to other treatments (Table 2). Figure 2 shows the increase in leaf number in the $3^{\text {rd }}, 5^{\text {th }}$ and $7^{\text {th }}$ week of observation for all treatments. Similar trend with plant height parameter also occurred in leaf number though it was less apparent. Leaf number of sweet corn would increase to a certain level (P3 dosage) then decrease afterwards.

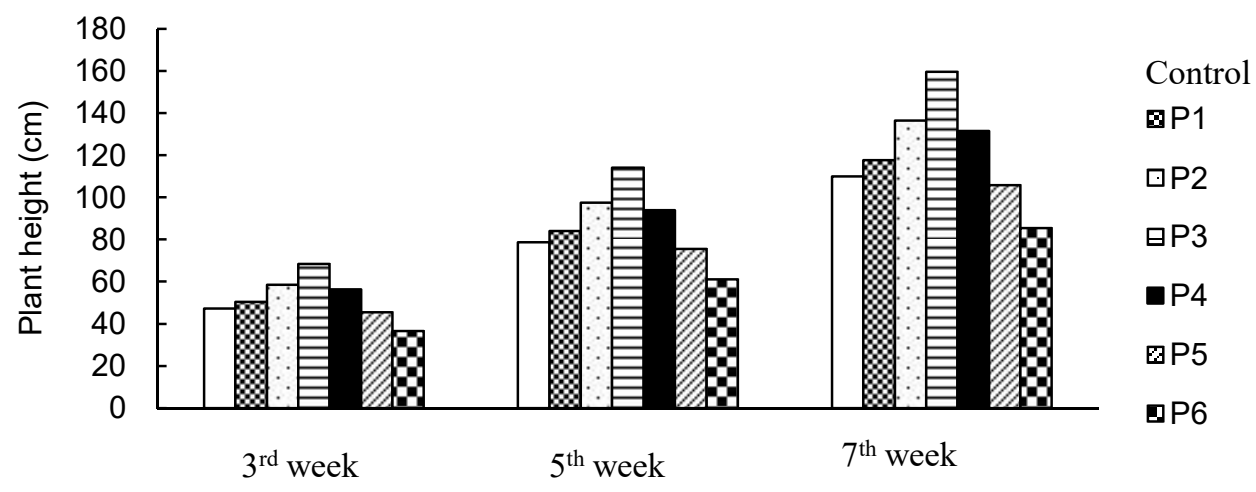

Figure 1 - The increment of sweet corn plant height due to liquid fertilizer application

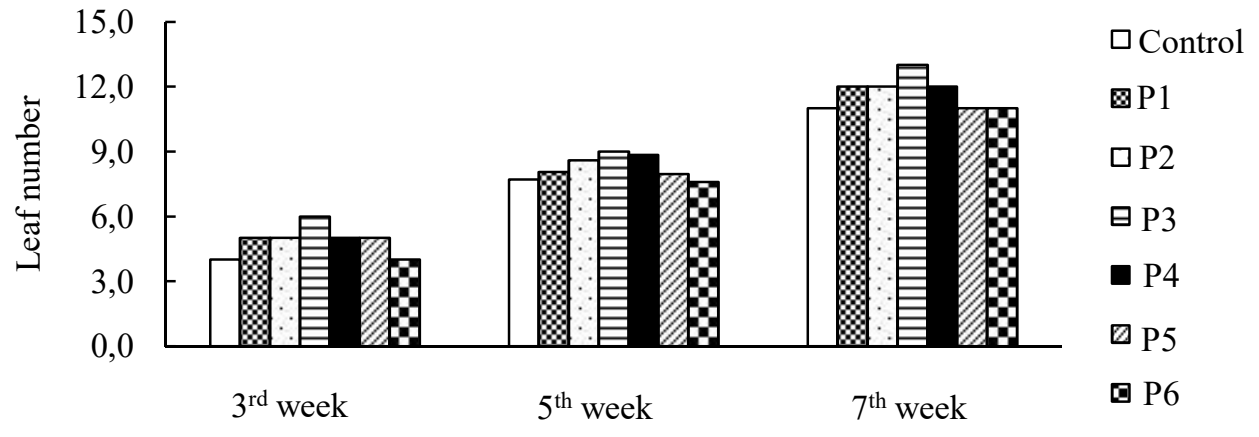

Figure 2 - The increment of sweet corn leaf number due to liquid fertilizer application

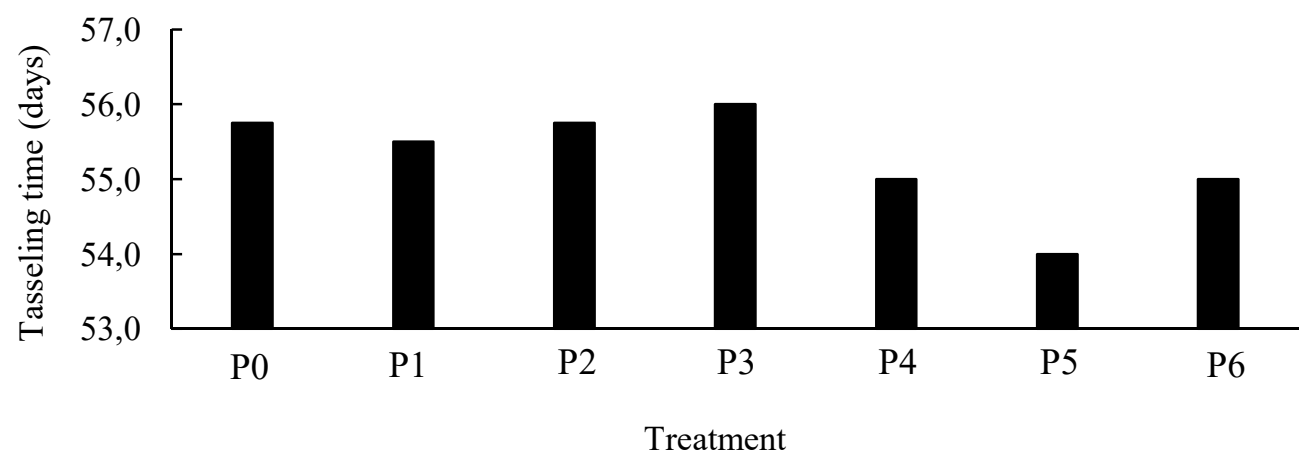

Figure 3 - The effect of liquid fertilizer application on tasseling time of sweet corn

The trend resulted in both parameters indicated that $\mathrm{P} 3(1,200 \mathrm{ml})$ was considered as the optimum dosage of liquid organic fertilizer for the growth of sweet corn. While P6 as the 
highest dosage $(2,400 \mathrm{ml})$ was considered too dense for corn growth resulting in the lowest results in these paramaters.

The application of liquid organic fertilizer did not affect sweet corn tasseling time (Table 1). However, P3 treatment apparently showed slower tasseling time compared to other treatments, while P5 was the fastest with 54 days. However, the margin was only about 2 days (Figure 3 ).

Yield Parameters. The application of liquid organic fertilizer from banana pseudostem had significantly affected all yield parameters on sweet corn as seen in Table 3 and Table 4.

Table 3 - The effect of liquid organic fertilizer application on cob weight with husk, cob weight with husk per plot, cob weight without husk, and cob weight without husk per plot of sweet corn

\begin{tabular}{lllll}
\hline Treatment & $\begin{array}{l}\text { Cob weight } \\
\text { with husk }(\mathrm{g})\end{array}$ & $\begin{array}{l}\text { Cob weight with husk } \\
\text { per plot }(\mathrm{kg})\end{array}$ & $\begin{array}{l}\text { Cob weight } \\
\text { without husk }(\mathrm{g})\end{array}$ & $\begin{array}{l}\text { Cob weight without } \\
\text { husk per plot }(\mathrm{kg})\end{array}$ \\
\hline Control & $231.87 \mathrm{~b}$ & $9.28 \mathrm{~b}$ & $135.00 \mathrm{~b}$ & $5.40 \mathrm{~b}$ \\
$\mathrm{P} 1$ & $282.50 \mathrm{c}$ & $11.30 \mathrm{c}$ & $169.37 \mathrm{~d}$ & $6.78 \mathrm{~d}$ \\
$\mathrm{P} 2$ & $321.87 \mathrm{~d}$ & $12.88 \mathrm{~d}$ & $184.37 \mathrm{e}$ & $7.38 \mathrm{e}$ \\
$\mathrm{P} 3$ & $343.75 \mathrm{e}$ & $13.75 \mathrm{e}$ & $210.00 \mathrm{~g}$ & $8.40 \mathrm{~g}$ \\
$\mathrm{P} 4$ & $323.75 \mathrm{~d}$ & $12.95 \mathrm{~d}$ & $186.87 \mathrm{f}$ & $7.48 \mathrm{f}$ \\
P5 & $285.00 \mathrm{c}$ & $11.40 \mathrm{c}$ & $156.25 \mathrm{c}$ & $6.25 \mathrm{c}$ \\
P6 & $225.62 \mathrm{a}$ & $9.03 \mathrm{a}$ & $128.75 \mathrm{a}$ & $5.15 \mathrm{a}$ \\
\hline LSD 5\% & 17.84 & 0.20 & 11.34 & 0.08 \\
\hline
\end{tabular}

Means followed by the same letters in the same column are not significantly different at the 5\% LSD level.

Table 3 shows the parameters of cob weight with husk (g), cob weight with husk per plot $(\mathrm{kg})$, cob weight without husk ( $\mathrm{g})$, and cob weight without husk per plot $(\mathrm{kg})$, while Table 4 shows the data of cob length $(\mathrm{cm})$ and cob diameter $(\mathrm{cm})$. Based on the results, it was found that P3 treatment showed the best result in all observed yield parameters. In contrast, P6 treatment resulted the lowest in all yield parameters, even lower compared to control.

Table 4 - The effect of liquid organic fertilizer application on cob length and cob diameter of sweet corn

\begin{tabular}{lll}
\hline Treatment & Cob length $(\mathrm{cm})$ & Cob diameter $(\mathrm{cm})$ \\
\hline Control & $18.40 \mathrm{~b}$ & $3.80 \mathrm{ab}$ \\
P1 & $18.56 \mathrm{~b}$ & $3.94 \mathrm{~b}$ \\
P2 & $20.74 \mathrm{c}$ & $4.08 \mathrm{c}$ \\
P3 & $25.23 \mathrm{~d}$ & $4.44 \mathrm{~d}$ \\
P4 & $20.74 \mathrm{c}$ & $4.08 \mathrm{c}$ \\
P5 & $17.83 \mathrm{ab}$ & $3.87 \mathrm{~b}$ \\
P6 & $16.48 \mathrm{a}$ & $3.71 \mathrm{a}$ \\
\hline LSD 5\% & 1.44 & 0.14 \\
\hline
\end{tabular}

Means followed by the same letters in the same column are not significantly different at the $5 \%$ LSD level.

The results of yield parameters indicated similar trend with growth parameters where yield parameters would increase following the increase of fertilizer dosages but then would start decreasing after reaching the optimum level at P3. Then it was obvious that P3 was the best treatment in this study by showing better performance in both growth and yield parameters compared to other treatments. Lower concentration dosage was considered did not supply enough nutrients for plants, while too concentrated dosage would also not benefit plants' growth. Proper dosage of fertilization would be beneficial in order to obtain the optimal result (Sudarsana, 2000; Rahmi and Jumiati, 2007).

\section{CONCLUSION}

The conclusions of this research included: 1) the application of 1,200 $\mathrm{ml}$ of banana pseudostem liquid organic fertilizer per plot showed the best results on all growth and yield parameters observed compared to other treatments; 2) the yield resulted from the application of $1,200 \mathrm{ml}$ of banana pseudostem liquid organic fertilizer reaching $13.75 \mathrm{~kg}$ (witth husk) and 
$8.40 \mathrm{~kg}$ (without husk) per plot. Based on the results, it was suggested for further research to evaluate the application of liquid organic fertilizer from banana pseudostem on other plant commodities. The information will be beneficial in confirming the effect of banana pseudostem utilization as potential resource for organic fertilizer.

\section{REFERENCES}

1. Bahtiar, S.A., A. Muayyad, L. Ulfaningtias, J. Anggara, C. Priscilla, and Miswar. 2016. Banana weevil compost application on growth and sugar content of sweet corn (Zea mays Saccharata). Agritrop J. Ilmu-ilmu Pertanian 14(1): 18-22. (in Indonesian)

2. Martajaya, M., L. Agustina, and Syekhfani. 2010. Organic Sweet Corn Cultivation in Tlogomas, Malang. J. Pembangunan dan Alam Lestari 1(1): 2087- 3522. (in Indonesian)

3. Nasution, F.J., L. Mawarni, and Meiriani. 2014. The application of solid and liquid organic fertilizer from banana pseudostem on growth and yield of Brassica juncea L. J. Agroekoteknologi 2(3): 1029-1037. (in Indonesian)

4. Rahmi, A and Jumiati. 2007. The effect of concentration and timing of application of super $\mathrm{ACl}$ foliar organic fertilizer on the growth and yield of sweet corn. Agritrop 26 (3): 105-109. (in Indonesian)

5. Sudarsana, K. 2000. The Application of Effective Microorganism-4 (EM-4) and compost on yield of sweet corn (Zea mays saccharata Sturt) in Entisols Soil. Frontir 32: 1-6. (in Indonesian)

6. Sugiarti, H. 2011. The application of banana pseudostem compost on seedling growth of jabon (Anthocephalus cadamba Miq). Dept of Silviculture. Faculty of Forestry, Bogor Agricultural University. (in Indonesian)

7. Suprihatin. 2011. Production process of liquid fertilizer from banana trunk. J. Teknik Kimia 5(2): 429-433.

8. Toonsiri, P., S.J. Del Grosso, A. Sukor, and J.G. Davis. 2016. Greenhouse gas emissions from solid and liquid organic fertilizers applied to lettuce. J. Environ. Qual. 45(6): 18121821. 